\title{
Content in metallic ions of wines from the Madeira and Azores archipelagos
}

\author{
Juan P. Pérez Trujillo ${ }^{\mathrm{a}, *}$, José E. Conde ${ }^{\mathrm{a}}$, María L. Pérez Pont ${ }^{\mathrm{a}}$, J. Câmara ${ }^{\mathrm{b}}$, José C. Marques ${ }^{\mathrm{b}}$ \\ ${ }^{a}$ Department of Analytical Chemistry, Nutrition and Food Sciences, Faculty of Chemistry, University of La Laguna, 38207 La Laguna, Tenerife, Spain \\ ${ }^{\mathrm{b}}$ Department of Chemistry, University of Madeira, Portugal
}

\section{A R T I C L E I N F O}

\section{Article history:}

Received 10 February 2010

Received in revised form 8 April 2010

Accepted 16 June 2010

\section{Keywords:}

Metals

Wines

Multivariate analysis

Azores

Madeira

\begin{abstract}
A B S T R A C T
This study determines for the first time $\mathrm{Na}, \mathrm{K}, \mathrm{Ca}, \mathrm{Mg}, \mathrm{Fe}, \mathrm{Cu}, \mathrm{Zn}, \mathrm{Mn}, \mathrm{Sr}$, $\mathrm{Li}$ and $\mathrm{Rb}$ contents in wines from the archipelagos of Madeira and Azores (Portugal). The greater part of the mean content for the different parameters fell within the ranges described in the literature, except for sodium whose higher content may be due to the effect of marine spray. ANOVA was used to establish the metals with significant differences in mean content between the wines from both archipelagos, between table and liquor wines of Madeira, and between wines of Pico and Terceira Islands from the Azores archipelago. Principal component analysis shows differences in the wines according to the wine-making process and/or the equipment employed. Stepwise linear discriminant analysis achieves a good classification and validation of wines according to the archipelago of origin, and the island in the case of Azores wines.
\end{abstract}

(c) 2010 Elsevier Ltd. All rights reserved.

\section{Introduction}

The authentication of wines, and food products in general, is of great interest to prevent fraud and to guarantee their origin and quality. It is thus very important to determine the chemical composition of wines and to study the factors that influence their composition. With this aim several constituents such as the conventional parameters, volatile compounds, aminoacids, metals, etc., have been analysed.

Metals appear to be the best way to identify the geographical origin due to their direct correlation with soil composition (Medina, 1996). Moreover, knowledge of the metallic ion concentration of wines is of interest because of their influence on the wine-making process where metals such as potassium, calcium, iron and copper can produce precipitates or cause cloudiness, the low acceptance levels for some metals set by the international community and, their importance in nutrition and their potentially toxic effects.

However, the mineral composition of wines depends not only on the soil composition where the vines were grown, but also on growing practices (fertilisation, phytosanitary treatments, etc.), technical equipment employed in the wineries (machinery, piping, etc.), oenological practices (use of fining agents, additives, etc.), environmental contamination (cars, factories, etc.) and fraudulent practices (use of forbidden chemicals) which could cause problems in their authentication (Eschnauer, 1982).

\footnotetext{
* Corresponding author. Tel.: +34 922318036; fax: +34 922318003.

E-mail address: jperez@ull.es (J.P. Pérez Trujillo).
}

The application of pattern recognition techniques, such as principal component analysis, cluster analysis, discriminant analysis, etc., has been very useful in the task of authentication (Forina, Armanino, Castino, \& Ubigli, 1986). These techniques have been applied to characterise wines from different regions of a country such as France (Medina \& Van Zeller, 1984), Italy (Moret, Scarponi, \& Cescon, 1994), Spain (Gonzálvez, Llorens, Cervera, Armenta, \& de la Guardia, 2009; Paneque, Alvarez, \& Gómez, 2009), Germany (Danzer, Calle, Thiel, \& Reichenbächer, 1999), the Czech Republic (Kment et al., 2005), Argentina (Fabani et al., 2010), or among different countries (Serapinas et al., 2008).

The Macaronesian region includes the archipelagos of Azores, Madeira, the Canary Islands and Cape Verde, all of them of volcanic origin, the three first regions being producers of wines. The composition of wines from the Canary Islands has been established, important differences of mean content being observed among the wines from the different islands which has permitted their differentiation according to their geographic origin (Barbaste, Medina, Sarabia, Ortiz, \& Pérez-Trujillo, 2002; Díaz, Conde, Estévez, Pérez Olivero, \& Pérez-Trujillo, 2003; Frías, Conde, Rodríguez Bencomo, García, \& Pérez-Trujillo, 2003; Pérez Trujillo, Barbaste, \& Medina, 2003).

Contrarily, at present, no data is available in the literature about the mineral content of bottled wines from Madeira and Azores archipelagos bearing the certified labels of denomination of origin.

In Madeira, the main wine produced is liquor (fortified) wine, which has been the traditional wine for the last three centuries, playing an important role in the economy of the island. This wine is elaborated with a partial alcoholic fermentation, between 4 and 
7 vol.\%, reserving sugar in variable amounts according to the type of wine (from dry to sweet), and with the subsequent addition of alcohol to $18-20 \mathrm{vol} . \%$. Subsequently the wine undergoes a process called "estufagem" at a temperature of $50-55^{\circ} \mathrm{C}$ during a period of 90 days to ensure fast oxidation. This process takes place in old wood casks or in cement containers. Finally it is aged in casks, cuves inox or cement containers lined with epoxy resins. The production of liquor wines in the Azores is very small and therefore this type of wine has not been included in this study.

In the last 10 years, both in Madeira and in the Azores the elaboration of table wines has become increasingly important and their production has increased accordingly. These wines, elaborated in the usual way, without the addition of alcohol, have a lower alcoholic degree, usually between 11.5 and 13.5 vol.\%.

The aim of this work is to determine the content of 11 metals: K, $\mathrm{Na}, \mathrm{Ca}, \mathrm{Mg}$, Fe, Cu, Zn, Mn, Sr, $\mathrm{Li}$ and $\mathrm{Rb}$ in wines of the Madeira and Azores archipelagos with a view to studying the levels of these metals and the risk of precipitations, to compare them with other volcanic islands from the same area (Canaries) and typify these wines using univariate and multivariate of data analysis techniques.

\section{Experimental}

\subsection{Samples}

Sixty-four samples of liquor and table wines produced in 2005 and 2006 by Madeira and Azores Archipelagos wine cellars were analysed. The distribution of samples was as follows: 28 samples from the Azores Archipelago (14 samples from Pico Island, 13 samples from Terceira Island and one sample from Graciosa Island), and 36 samples from Madeira, 15 of which were table wines and 21 were liquor wines. The alcoholic degree was $11.5-13.5 \%$ for the table wines and 18-20\% for liquor wines. Wines from Azores had the appelation "Vinho Regional Açores", table wine from Madeira "Denominação de Origen Protegida Madeirense" and liquor wines from Madeira "Denominação de Origen Protegida Madeira".

Wines from the Standards Measurement and Testing Programme (Community Bureau of Reference, Brussels, EU), BCR C (dry white), BCR D (sweet) and BCR E (red) were routinely used in order to perform quality control of measurement.

\subsection{Reagents and solutions}

All chemicals were of analytical grade. Stock solutions of each metal Na, K, Ca, Mg, Fe, Cu, Zn, Mn, Sr, Li, and Rb $1000 \pm 0.002$ $\mathrm{mg} / \mathrm{l}$ were from Panreac (Barcelona, Spain). Working standard solutions were obtained by suitable dilution from stock solution. Lithium chloride 99\% as ionic suppressor from Fluka (Buchs, Switzerland). Lanthanum chloride $99 \%$ as molecular suppressor from Riedel de Haën (Seelze, Germany). Nitric acid 65\% from Panreac. Ultrapure water from Milli-Q system (Millipore, Bedford, USA) with a conductivity of $18 \mathrm{M} \Omega$ was used throughout.

\subsection{Apparatus}

A CEM MDS-81D microwave oven, equipped with 12 Teflon PFA and reaching an internal pressure of $830 \mathrm{kPa}$, was used for wine sample digestion.

A Varian Spectra AA-10 Plus spectrophotometer was used for metal determination involving atomic absorption spectrometry (AAS) and atomic emission spectrometry (AES). It is equipped with unielemental hollow cathode lamps, a Czerny-Turner type monochromator, a Mark VI type gas-burner, a photomultiplier and a deuterium lamp background correction system.

\subsection{Analytical procedures}

Metals $\mathrm{Na}, \mathrm{K}, \mathrm{Ca}, \mathrm{Mg}$, Fe, $\mathrm{Cu}, \mathrm{Zn}$, and $\mathrm{Mn}$ were determined from ASS using an air/acetylene flame, and Sr using acetylene/nitrous oxide flame. Metals Li and Rb were measured from AES. Major elements ( $\mathrm{Na}, \mathrm{K}, \mathrm{Ca}$ and $\mathrm{Mg}$ ) were analysed by dilution of the wine samples. For minor and trace elements (Fe, $\mathrm{Cu}, \mathrm{Zn}, \mathrm{Mn}, \mathrm{Sr}$, Li and $\mathrm{Rb}$ ), due to the matrix effect, the samples were previously digested with nitric acid in a microwave oven. All results were the average of triplicate measurements.

Wines from the Standards Measurement and Testing Programme (Community Bureau of Reference, Brussels, EU), BCR C (dry white), BCR D (sweet) and BCR E (red) were submitted to the same digestion procedures.

\subsection{Univariate analysis}

Univariate characterisation of the wines by geographical origin or type of wine was carried out based on Fisher's weight $(F)$ by means of analysis of variance (one-way ANOVA) applied to compare the mean values obtained among the different categories.

\subsection{Multivariate analysis}

A matrix was constructed with rows representing wine samples and columns corresponding to metals $\mathrm{Na}, \mathrm{K}, \mathrm{Ca}, \mathrm{Mg}, \mathrm{Fe}, \mathrm{Cu}, \mathrm{Zn}, \mathrm{Mn}$, $\mathrm{Sr}$, Li and $\mathrm{Rb}$. A data pretreatment was made in order to avoid the differences in measurement units. Autoscaling is the most widely used scaling technique. The result is a variable with zero mean and a unit standard deviation (Kowalski \& Bender, 1972).

Principal component analysis (PCA) was used to study the relationship between variables and observations, as well as recognising the data structure (Mardia, Kent, \& Bibby, 1979).

Linear discriminant analysis (LDA) was used for classification purposes (Wold et al., 1984). Stepwise LDA was used to select the more discriminant variables (Powers \& Keith, 1968). Leaveone-out cross validation test was used to validate the results of classification (Ramis-Ramos \& García-Alvarez, 2001).

\subsection{Software}

Univariate and multivariate analyses were performed by means of the statistical software package STATGRAPHICS Plus for Windows 4.0 from Statistical Graphics Corporation. All data were autoscaled before use.

\section{Results and discussion}

\subsection{Mineral content of wine samples}

The mean and the standard deviation for the metals $\mathrm{K}, \mathrm{Na}, \mathrm{Ca}$, $\mathrm{Mg}, \mathrm{Fe}, \mathrm{Cu}, \mathrm{Zn}, \mathrm{Mn}, \mathrm{Sr}, \mathrm{Li}$ and $\mathrm{Rb}$ in wines from the Azores and Madeira Archipelagos, as well as significant differences in mean content among both archipelagos are presented in Table 1.

The mean content for the majority of these metals in the wines of both archipelagos are consistent with the values described in the literature for those metals in other wines (Cabanis \& Cabanis, 2000; Eschnauer, 1986; Greenouch, Longerich, \& Jackson, 1997). In the case of sodium the wines of Madeira and Azores yielded higher values than those described in the greater part of the literature consulted, 3-30 mg/l (Jos, Moreno, González, \& Repetto, 2004; Thiel \& Danzer, 1997). However, the values found here are similar to those observed in grapes from vines exposed to a considerable influence of the sea, as in the present case (Frías, Pérez Trujillo, Peña, \& Conde, 2001; Salaha \& Voudouri, 1991), so this 
Table 1

Mean values and standard deviation of the different metals $\left(\mathrm{mg} \mathrm{l}^{-1}\right)$ in Azores and Madeira wines, and significant differences between both archipelagos.

\begin{tabular}{lrrrl}
\hline & \multicolumn{1}{l}{$\begin{array}{l}\text { Azores } \\
(n=28)\end{array}$} & \multicolumn{1}{l}{$\begin{array}{l}\text { Madeira } \\
(n=36)\end{array}$} & \multicolumn{1}{l}{$F$} & $p$ \\
\hline $\mathrm{K}$ & $923 \pm 217$ & $936 \pm 215$ & 0.06 & 0.8053 \\
$\mathrm{Na}$ & $57.7 \pm 30.5$ & $51.0 \pm 30.1$ & 0.55 & 0.4612 \\
$\mathrm{Ca}$ & $80.5 \pm 15.7$ & $73.1 \pm 23.8$ & 1.99 & 0.1637 \\
$\mathrm{Mg}$ & $112.5 \pm 41.8$ & $101.2 \pm 13.9$ & 2.33 & 0.1324 \\
$\mathrm{Fe}$ & $1.55 \pm 0.96$ & $2.35 \pm 1.37$ & 6.92 & 0.0107 \\
$\mathrm{Cu}$ & $0.22 \pm 0.41$ & $0.63 \pm 0.66$ & 8.34 & 0.0053 \\
$\mathrm{Zn}$ & $0.63 \pm 0.55$ & $1.02 \pm 0.60$ & 7.19 & 0.0094 \\
$\mathrm{Mn}$ & $0.71 \pm 0.22$ & $1.93 \pm 0.76$ & 68.59 & 0.0000 \\
$\mathrm{Sr}$ & $0.76 \pm 0.29$ & $0.66 \pm 0.25$ & 2.24 & 0.1399 \\
$\mathrm{Li}$ & $4.87 \pm 4.83$ & $3.92 \pm 4.53$ & 0.65 & 0.4239 \\
$\mathrm{Rb}$ & $2.69 \pm 0.70$ & $1.94 \pm 0.64$ & 19.63 & 0.0000 \\
\hline
\end{tabular}

$F=$ between-group and within group variances ratio. $p=$ significance level ${ }^{\text {a }} \mu \mathrm{gl}^{-1}$.

greater content of sodium in the wines from Madeira and Azores can be also attributed to the effect of marine spray.

Iron can cause problems in wines, particularly when iron equipment is used in the elaboration process. Sixty-two samples (97\%) of wines had a content lower than $5.0 \mathrm{mg} / \mathrm{l}$, only two samples of liquor wines of Madeira having a content of $5.7 \mathrm{mg} / \mathrm{l}$, far below the $10 \mathrm{mg} / \mathrm{l}$ considered to be the minimum necessary to produce ferric cloudiness (Ough, 1992).

Copper is another metal whose content could be affected by the technology of the cellar (use of brass valves, etc.), as well as by phytosanitary treatment against oidium. It is well known that copper in a reductor atmosphere can originate cupric cloudiness (Ough, 1992), and a high content can have toxic effects. For these reasons the International Office of Vine and Wine (OIV, 1990) recommended a maximum limit of $1 \mathrm{mg} / \mathrm{l}$ for this element. Although some samples of Madeira wines exceed this limit, which could be related with the technology of the cellar (use of brass valves, etc.), or a particular phytosanitary treatment, the mean content of both archipelagos, $0.22 \mathrm{mg} / \mathrm{l}$ Azores and $0.63 \mathrm{mg} / \mathrm{l}$ Madeira is lower than the recommended maximum limit.

Zinc is also related with technological processes and the use of certain phytosanitary products, being another metal for which the OIV has established a maximum limit of $5 \mathrm{mg} / \mathrm{l}$. All the analysed wines showed a concentration below $3 \mathrm{mg} / \mathrm{l}$.

If the results obtained for the wines of both archipelagos are compared it can be observed that wines from Azores showed a higher mean content in $\mathrm{Na}, \mathrm{Ca}, \mathrm{Mg}, \mathrm{Sr}$ and $\mathrm{Li}$ and a lower content in $\mathrm{K}$ than wines from Madeira, but these differences were not significant. On the contrary, wines from Madeira showed a higher significant mean content in $\mathrm{Fe}, \mathrm{Cu}, \mathrm{Zn}$ and $\mathrm{Mn}$, and a lower significant mean content in $\mathrm{Rb}$ than Azores wines. The first three features are related by equipment used in the elaboration processes.

\subsection{Comparison of the content in metals between table and liquor wines from Madeira}

The mean and the standard deviation for the different metals in table and liquor wines from Madeira, and the significant differences in mean content between both types of wines are presented in Table 2

As can be seen in Table 2 the potassium, sodium, zinc, strontium and lithium metals did not show significant differences in mean content between both types of wines. However, calcium, magnesium and rubidium showed a higher significant mean content in the table wines, and iron, copper and manganese in the liquor wines. These differences could be related with differences in solubility of some metallic salts as a function of the alcoholic degree
Table 2

Mean values and standard deviation of the different metals $\left(\mathrm{mg} \mathrm{l}^{-1}\right)$ of table and liquor wines from Madeira Island, and significant differences according type of wine.

\begin{tabular}{lclrl}
\hline & $\begin{array}{l}\text { Table wines } \\
(n=15)\end{array}$ & $\begin{array}{l}\text { Liquor wines } \\
(n=21)\end{array}$ & $F$ & $p$ \\
\hline $\mathrm{K}$ & $1012 \pm 302$ & $882 \pm 98$ & 3.42 & 0.0731 \\
$\mathrm{Na}$ & $52.3 \pm 24.0$ & $50.1 \pm 34.3$ & 0.05 & 0.8293 \\
$\mathrm{Ca}$ & $89.3 \pm 19.5$ & $61.6 \pm 19.7$ & 17.40 & 0.0002 \\
$\mathrm{Mg}$ & $109.1 \pm 12.6$ & $95.5 \pm 11.9$ & 10.89 & 0.0023 \\
$\mathrm{Fe}$ & $1.42 \pm 0.77$ & $3.02 \pm 1.33$ & 17.33 & 0.0002 \\
$\mathrm{Cu}$ & $0.30 \pm 0.35$ & $0.86 \pm 0.73$ & 7.43 & 0.0100 \\
$\mathrm{Zn}$ & $0.88 \pm 0.62$ & $1.13 \pm 0.56$ & 1.57 & 0.2181 \\
$\mathrm{Mn}$ & $1.45 \pm 0.84$ & $2.27 \pm 0.47$ & 14.09 & 0.0007 \\
$\mathrm{Sr}$ & $0.62 \pm 0.17$ & $0.69 \pm 0.30$ & 0.76 & 0.3881 \\
$\mathrm{Li}$ & $2.51 \pm 2.14$ & $4.93 \pm 5.49$ & 2.63 & 0.1143 \\
$\mathrm{Rb}$ & $2.57 \pm 0.46$ & $1.57 \pm 0.26$ & 68.73 & 0.0000 \\
\hline
\end{tabular}

$F=$ between-group and within group variances ratio. $p=$ significance level.

a $\mu \mathrm{g} \mathrm{l}-1$

( $\mathrm{Ca}, \mathrm{Mg}$ and $\mathrm{Rb}$ ), and/or differences in the equipment used in the elaboration of both types of wines due to the "stufagem" process (Fe, $\mathrm{Cu}$ and $\mathrm{Mn}$ ).

\subsection{Comparison of the content in metals between the wines of Pico and Terceira Islands, Azores archipelago}

Pico and Terceira are the main islands producing wine in the Azores archipelago. The mean and the standard deviation of the different metals in wines from Pico and Terceira Islands, and the significant differences in mean content between both islands are presented in Table 3.

As can be seen in the table, the majority of the ionic metals did not show significant differences in mean content between both islands. Only calcium, manganese and rubidium showed a higher significant mean content in Terceira Island.

\subsection{Comparison of the metallic content with those of wines from other} volcanic islands of the same area: Canary Islands

Taking into account the fact that the Canary Islands archipelago is situated in the same area of the Atlantic as the Madeira and Azores archipelagos, all three of volcanic origin, we considered it worthwhile to compare the results obtained for the wines from Madeira and the Azores with those from the Canaries.

For that purpose we have chosen the islands of La Palma, Tenerife and Lanzarote because these are the islands with the highest wine production in the Canary Islands, and because they are situated in the western, central and eastern parts of the

Table 3

Mean values and standard deviation of the different metals $\left(\mathrm{mg} \mathrm{l}^{-1}\right)$ in wines from Pico and Terceira Islands (Azores), and significant differences between both islands.

\begin{tabular}{lcccl}
\hline & $\begin{array}{l}\text { Pico } \\
(n=14)\end{array}$ & $\begin{array}{l}\text { Terceira } \\
(n=13)\end{array}$ & $F$ & $p$ \\
\hline $\mathrm{K}$ & $906 \pm 292$ & $943 \pm 111$ & 0.19 & 0.6703 \\
$\mathrm{Na}$ & $50.1 \pm 14.0$ & $53.5 \pm 19.0$ & 0.28 & 0.5994 \\
$\mathrm{Ca}$ & $74.3 \pm 11.8$ & $88.4 \pm 16.3$ & 6.69 & 0.0159 \\
$\mathrm{Mg}$ & $119.9 \pm 49.8$ & $106.4 \pm 33.1$ & 0.68 & 0.4169 \\
$\mathrm{Fe}$ & $1.66 \pm 1.11$ & $1.40 \pm 0.84$ & 0.49 & 0.4924 \\
$\mathrm{Cu}$ & $0.14 \pm 0.14$ & $0.31 \pm 0.58$ & 1.14 & 0.2964 \\
$\mathrm{Zn}$ & $0.57 \pm 0.51$ & $0.72 \pm 0.61$ & 0.52 & 0.4774 \\
$\mathrm{Mn}$ & $0.64 \pm 0.17$ & $0.81 \pm 0.24$ & 4.63 & 0.0414 \\
$\mathrm{Sr}$ & $0.70 \pm 0.31$ & $0.86 \pm 0.22$ & 2.60 & 0.1191 \\
$\mathrm{Li}$ & $5.91 \pm 5.25$ & $4.05 \pm 4.39$ & 0.99 & 0.3297 \\
$\mathrm{Rb}$ & $2.36 \pm 0.56$ & $3.15 \pm 0.44$ & 16.09 & 0.0005 \\
\hline
\end{tabular}

$F=$ between-group and within group variances ratio. $p=$ significance level. ${ }^{\mathrm{a}} \mu \mathrm{g} \mathrm{l^{-1 }}$. 
Table 4

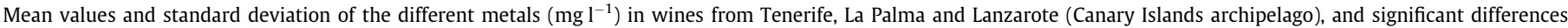
among them.

\begin{tabular}{|c|c|c|c|c|c|c|}
\hline & $\begin{array}{l}\text { Tenerife }(1) \\
(n=188)\end{array}$ & $\begin{array}{l}\text { La Palma (2) } \\
(n=23)\end{array}$ & $\begin{array}{l}\text { Lanzarote (3) } \\
(n=38)\end{array}$ & $F$ & $p$ & Sig. dif. $p<0.05$ \\
\hline $\mathrm{K}$ & $812 \pm 328$ & $967 \pm 333$ & $871 \pm 358$ & 2.47 & 0.087 & - \\
\hline $\mathrm{Na}$ & $86.5 \pm 40.0$ & $50.8 \pm 26.2$ & $144.1 \pm 36.7$ & 50.0 & 0.000 & $1-2,1-3,2-3$ \\
\hline $\mathrm{Ca}$ & $68.6 \pm 15.8$ & $68.7 \pm 12.0$ & $69.5 \pm 13.1$ & 0.06 & 0.938 & - \\
\hline $\mathrm{Mg}$ & $87.4 \pm 17.3$ & $68.9 \pm 5.14$ & $76.4 \pm 12.6$ & 18.9 & 0.000 & $1-2,1-3$ \\
\hline $\mathrm{Fe}$ & $2.32 \pm 0.92$ & $2.57 \pm 1.23$ & $3.89 \pm 1.96$ & 28.4 & 0.000 & $1-3,2-3$ \\
\hline $\mathrm{Cu}$ & $0.18 \pm 0.23$ & $0.15 \pm 0.13$ & $0.13 \pm 0.11$ & 0.98 & 0.376 & - \\
\hline $\mathrm{Zn}$ & $0.62 \pm 0.31$ & $0.38 \pm 0.32$ & $0.38 \pm 0.28$ & 13.7 & 0.000 & $1-2,1-3$ \\
\hline Mn & $1.12 \pm 0.46$ & $0.40 \pm 0.13$ & $0.84 \pm 0.19$ & 35.8 & 0.000 & $1-2,1-3,2-3$ \\
\hline $\mathrm{Sr}$ & $0.60 \pm 0.22$ & $1.19 \pm 0.24$ & $0.70 \pm 0.29$ & 63.8 & 0.000 & $1-2,1-3,2-3$ \\
\hline $\mathrm{Li}^{\mathrm{a}}$ & $6.70 \pm 3.15$ & $7.96 \pm 3.76$ & $18.86 \pm 8.11$ & 125.2 & 0.000 & $1-3,2-3$ \\
\hline $\mathrm{Rb}$ & $2.12 \pm 0.82$ & $3.05 \pm 0.88$ & $0.22 \pm 0.13$ & 122.5 & 0.000 & $1-2,1-3,2-3$ \\
\hline
\end{tabular}

$F=$ between-group and within group variances ratio. $p=$ significance level.

${ }^{\mathrm{a}} \mu \mathrm{g} \mathrm{l}^{-1}$.

archipelago, respectively, and are of different geological ages (Lanzarote: 20.6; Tenerife: 11.9 and La Palma: 1.77 millions years old).

In Table 4 we present the content in the different metals in wines from the Canary Islands (Conde, Estévez, Rodríguez Bencomo, García Montelongo, \& Pérez-Trujillo, 2002; Díaz et al., 2003; Frías et al., 2003).

Significant differences can be observed in the mean values between the different Canary Islands for all the elements with the exceptions of potassium, calcium and copper. Thus, the differences in mean content among the different Canary Islands are greater than between the islands of the Azores and even between the Madeira and Azores archipelagos.

A comparison of the wines of the three archipelagos (data no presented) reveals that potassium, calcium and strontium do not present significant differences in mean content among the three archipelagos. Magnesium and manganese present significant differences in mean value among the wines of the three archipelagos, with the maximum and minimum content, respectively, for the Azores and the Canaries in the case of magnesium and, Madeira and Azores in the case of manganese. Wines from Madeira show a significantly higher mean content than those from the other archipelagos in copper and zinc, features related to the equipment of the caves. Wines from the Azores show a significantly higher mean content in rubidium and a significantly lower one in iron than the wines from the other two archipelagos. Wines from the Canary Islands show a mean content in sodium and lithium that is significantly higher than those of the wines from the other two archipelagos. The content in sodium is high in all three archipelagos due to the effect of marine spray, but in the Canaries it is higher than in the other archipelagos, which may be due to the fact that the other two archipelagos have a wetter climate, with frequent rains that wash the vines, lessening the effect of the marine spray.

\subsection{Multivariate data analysis}

\subsubsection{Unsupervised techniques}

Although some interesting information is obtained according to the island of production by applying univariate analysis to the metal contents of the Madeira and Azores wines, differentiation of the wines is quite difficult with a single direct observation. When PCA was applied to the data matrix (64 samples and the more discriminant features: $\mathrm{Fe}, \mathrm{Cu}, \mathrm{Zn}, \mathrm{Mn}$ and $\mathrm{Rb}$ ) a total of two Principal Components ( $\mathrm{PC}$ ) were extracted with eigenvalues $>1$, which account for $65.0 \%$ of the total variance of the system. Table 5 shows the loading of each variable on each PC, and it can be seen that PC-1 (47.9\% total variance) is mainly associated positively to manganese, iron and copper, and PC-2 (17.1\% total variance) shows higher loading for zinc and rubidium.
Table 5

Loading of the variables, eigenvalues \% of variance and cumulative variance for each principal component.

\begin{tabular}{lcc}
\hline Element & PC 1 & PC 2 \\
\hline $\mathrm{Fe}$ & 0.477 & 0.047 \\
$\mathrm{Cu}$ & 0.397 & 0.194 \\
$\mathrm{Zn}$ & 0.371 & 0.774 \\
$\mathrm{Mn}$ & 0.521 & -0.281 \\
$\mathrm{Rb}$ & -0.454 & 0.530 \\
Eigenvalue & 2.397 & 1.025 \\
\% Variance & 47.94 & 17.08 \\
\% Cumulative & 47.94 & 65.02 \\
\hline
\end{tabular}

The plot of scores in the plane defined by PC- 1 and PC-2, Fig. 1, shows that samples from Madeira are in the central and right parts of the graph, the liquor wines of Madeira being the samples more to the right (in the address of $\mathrm{Fe}, \mathrm{Cu}$ and $\mathrm{Mn}$ ), Terceira wines are in the upper and left (in the address of $\mathrm{Rb}$ ) and Pico samples in the bottom and left parts. Thus, PC- 1 separates samples according to whether or not they have been submitted to the process of "estufagem". Thus, liquor wines of Madeira elaborated according to the "stufagem" process with positive scores tend to be separated from table wines, with negative scores, both from Azores and from Madeira. PC-2 tends to separate the samples of Terceira from those of Pico.

\subsubsection{Supervised techniques}

Linear discriminant analysis (LDA) was applied to classify wines according to archipelago, and island of origin in the case of Azores wines, using the two following processes: (1) stepwise LDA that selects the quantitative variables that enhance discrimination of the groups established by the dependent variable using Lambda of Wilks as the criterion; and (2) introduction of all independent vari-

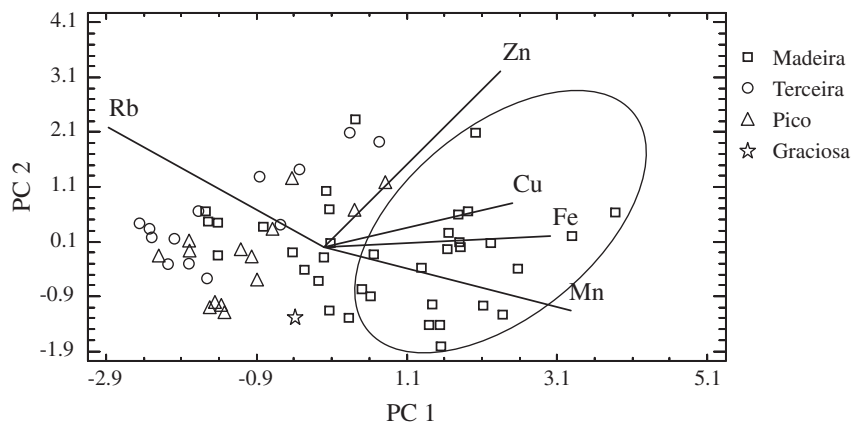

Fig. 1. Scores of the 64 samples of Madeira and Azores wines on the first two principal components (66.1\% of the total variance). Madeira liquor samples inside the circle. 
Table 6

Recognition and prediction abilities using stepwise LDA and leave-one-out.

\begin{tabular}{llllll}
\hline Archipelago & \multicolumn{2}{l}{$\begin{array}{l}\text { Total samples } \\
\mathrm{Na}, \mathrm{Ca}, \mathrm{Cu}, \mathrm{Zn}, \mathrm{Mn}, \mathrm{Sr}, \mathrm{Li}\end{array}$} & & & \multicolumn{2}{l}{\begin{tabular}{l} 
Samples from Azores \\
\cline { 2 - 3 }
\end{tabular}} & $\begin{array}{llllll}\text { All features except Mn } \\
\text { Recognition } \\
\text { ability (\%) }\end{array}$ & $\begin{array}{l}\text { Prediction } \\
\text { ability (\%) }\end{array}$ & & $\begin{array}{l}\text { Recognition } \\
\text { ability (\%) }\end{array}$ & $\begin{array}{l}\text { Prediction } \\
\text { ability (\%) }\end{array}$ \\
\hline Azores & 96.4 & 92.9 & Pico & 100.0 & 92.9 \\
Madeira & 86.1 & 86.1 & Terceira & 100.0 & 84.6 \\
Total & 90.6 & 89.0 & Total & 100.0 & 88.9 \\
\hline
\end{tabular}

ables in order to maintain all the original information. In both cases validation of these results was performed using leave-one-out cross validation.

When the stepwise LDA was applied, using archipelago as factor, seven variables ( $\mathrm{Na}, \mathrm{Ca}, \mathrm{Cu}, \mathrm{Zn}, \mathrm{Mn}, \mathrm{Sr}$ and $\mathrm{Li}$ ) were selected and one statistically significant discriminant function was obtained. In this way, $90.6 \%$ of recognition ability and $89.0 \%$ of prediction ability were obtained (Table 6). The results showed a higher classification and prediction abilities for Azores (96.4\% and 92.9\%, respectively) than for Madeira (86.1\%) wines.

When the stepwise LDA was applied to Azores samples, using island as factor, ten variables (all of them except manganese) were selected and one statistically significant discriminant function was obtained. In this way, $100 \%$ of recognition ability and $88.9 \%$ of prediction ability were obtained (Table 6).

\section{Conclusions}

The content in 11 metals was determined for the first time in 64 bottled wine samples belonging to the archipelagos of Azores and Madeira, bearing certification of the denomination of origin.

Wines from Madeira have a significantly higher mean content in $\mathrm{Fe}, \mathrm{Cu}, \mathrm{Zn}$ and $\mathrm{Mn}$ and a significantly lower $\mathrm{Rb}$ content than wines from Azores. These differences may be related with soil composition, winery equipment and the elaboration process employed.

Liquor wines from Madeira have a significantly higher mean content in $\mathrm{Fe}, \mathrm{Cu}$ and $\mathrm{Mn}$ and a significantly lower $\mathrm{Ca}, \mathrm{Mg}$ and $\mathrm{Rb}$ content than table wines, indicating that their content perhaps depends on the equipment and/or the elaboration process

Wines from Terceira have a significantly higher mean content in $\mathrm{Ca}, \mathrm{Mn}$ and $\mathrm{Rb}$ than wines from Pico. These differences appear to be related to soil composition.

When PCA was applied to the total samples of Madeira and Azores archipelago two principal components accounting for $65 \%$ of the total variance could be extracted, and the first PC showed a tendency to differentiate samples of liquor wines from Madeira from the remainder.

Stepwise linear discriminant analysis showed an acceptable degree of recognition and prediction abilities for samples according to the archipelago and island of origin.

\section{Acknowledgements}

This work was supported by Project CARVINMAC MAC/2.3/M51 and Project ANTIVINMAC MAC/2.3/M28. The authors thank Cooperativa Vitivinícola da ilha do Pico, Casa Agrícola Brum (Biscoitos, Terceira), and Instituto del Vino de Madeira for the supplied samples.

\section{References}

Barbaste, M., Medina, B., Sarabia, L., Ortiz, M. C., \& Pérez-Trujillo, J. P. (2002) Analysis and comparison of simca models for denominations of origin of wines from the Canary Islands (Spain) built by means of their trace and ultratrace metals content. Analytica Chimica Acta, 472, 161-174.

Cabanis, J. C., \& Cabanis, M. T. (2000). Tablas de composición. In C. Flanzy (Ed.), Enología: fundamentos científicos y tecnológicos (pp. 322). Madrid: Ed. Mundi Prensa.

Conde, J. E., Estévez, D., Rodríguez Bencomo, J. J., García Montelongo, F. J., \& PérezTrujillo, J. P. (2002). Characterization of bottled wines of Tenerife Island (Spain) by their metallic content. Italian Journal of Food Science, 14(4), 375-387.

Danzer, K., Calle, D., Thiel, G., \& Reichenbächer, M. (1999). Classification of wine samples according to origin and grape varieties on the basis of inorganic and organic trace analysis. American Laboratory, 31, 26-34.

Díaz, C., Conde, J. E., Estévez, D., Pérez Olivero, S. J., \& Pérez-Trujillo, J. P. (2003) Application of artificial neural networks for the differentiation of red wines from the Canary Islands according to the island of origin. Journal of Agricultural and Food Chemistry, 51(15), 4303-4307.

Eschnauer, H. (1982). Trace elements in must and wine: Primary and secondary contents. American Journal of Enology and Viticulture, 33, 226-230.

Eschnauer, H. (1986). Spureneelemente und Ultra-Spurenelemente in Wein. Naturwissenschaften, 73, 281-290.

Fabani, M. P., Arrúa, R. C., Vázquez, F., Díaz, M. P., Baroni, M. V., \& Wunderlin, D. A. (2010). Evaluation of elemental profile coupled to chemometrics to assess the geographical origin of Argentinean wines. Food Chemistry, 119, 372-379.

Forina, M., Armanino, C., Castino, M., \& Ubigli, M. (1986). Multivariate data analysis as a discriminating method of the origin of wines. Vitis, 25, 189-201.

Frías, S., Conde, J. E., Rodríguez Bencomo, J. J., García, F., \& Pérez-Trujillo, J. P. (2003). Classification of commercial wines from the Canary Islands (Spain) by chemometric techniques using metallic contents. Talanta, 59, 335-344.

Frías, S., Pérez Trujillo, J. P., Peña, E. M., \& Conde, J. E. (2001). Classification and differentiation of bottled sweet wines of Canary Islands (Spain) by their metallic content. European Food Research Technology, 213(2), 145-149.

Gonzálvez, A., Llorens, A., Cervera, M. L., Armenta, S., \& de la Guardia, M. (2009). Elemental fingerprint of wines from the protected designation of origin Valencia. Food Chemistry, 112, 26-34.

Greenouch, J. D., Longerich, H. P., \& Jackson, S. E. (1997). Element fingerprint of Okanagan Valley wines using ICP-MS: Relationship between wine composition, vineyards and wine color. Australian Journal of Grape and Wine Research, 3(2), $75-83$.

Jos, A., Moreno, A. G., González, G., \& Repetto, A. M. (2004). Differentiation of sparkling wines (cava and champagne) according to their mineral content. Talanta, 63, 377-382.

Kment, P., Mihaljevic, M., Ettler, V., Sebek, O., Strnad, L., \& Rohlova, L. (2005). Differentiation of Czech wines using multielemental composition. A comparison with vineyards soil. Food Chemistry, 91, 157-165.

Kowalski, B. R., \& Bender, C. F. (1972). Pattern recognition. A powerful approach to interpreting chemical data. Journal of the American Chemical Society, 94, 5632-5639.

Mardia, K. W., Kent, J. T., \& Bibby, J. M. (1979). Multivariate analysis. New York: Academic Press.

Medina, B. (1996). Wine authenticity. In P. R. Ashurst \& M. J. Dennis (Eds.), Food authentication (pp. 60-107). London: Blackie.

Medina, B., \& Van Zeller, A. L. (1984). Différentiation des Vins de Trois Régions de France. Connaissance Vigne Vin, 14, 79-96.

Moret, I., Scarponi, G., \& Cescon, P. (1994). Chemometric characterization and classification of five Venetian white wines. Journal of Agricultural and Food Chemistry, 42, 1143-1153.

OIV (1990). Recueil des méthodes internationales d'analyse des vins et des moûts. Annexe C. París: OIV.

Ough, C. S. (1992). Estabilización. In T. Cook (Ed.), Tratado básico de enología (pp. 157-159). Zaragoza: Ed. Acribia.

Paneque, P., Alvarez, M. T., \& Gómez, I. (2009). Metal contents in "oloroso" sherry wines and their classification according to provenance. Food Chemistry, 117, 302-305.

Pérez Trujillo, J. P., Barbaste, M., \& Medina, B. (2003). Chemometric study of bottled wines with denomination of origin from the Canary Islands (Spain) based on ultratrace elemental content determined by ICP-MS. Analytical Letters, 36(3), 679-697.

Powers, J. J., \& Keith, E. S. (1968). Stepwise discriminant analysis of gas chromatographic data an aid in classifying the flavor quality of foods. Journal of Food Sciences, 36, 207-215.

Ramis-Ramos, G., \& García-Alvarez, M. C. (2001). Quimiometría (pp. 193-195). Madrid: Editorial Sintesis.

Salaha, M. J., \& Voudouri, M. (1991). F.V. o 888/MOD. 1, 1834/230791.

Serapinas, P., Venskutonis, P. R., Aninkevicius, V., Ezerinskis, Z., Galdikas, A., \& Juzikiene, V. (2008). Step by step approach to multielemental analysis in testing the provenance of wines. Food Chemistry, 107, 1652-1660.

Thiel, G., \& Danzer, K. (1997). Direct analysis of mineral components in wine by inductively coupled plasma optical emission spectrometry (ICP-OES). Fresenius Journal of Analytical Chemistry, 357, 553-557.

Wold, S., Albano, C., Dum, W. J., Edlund, U., Esbensen, K., Geladi, P., et al. (1984). Multivariate data analysis in chemistry. In B. R. Kowalski (Ed.), Chemometrics, mathematics and statistics in chemistry (pp. 17-96). Holland: Riedel Publishing. 